\title{
Spray Drying of Cubosomes for Oral Vaccine Delivery
}

von Halling Laier, Christoffer; Abid, Zarmeena; Weydahl, Ingrid Elise Konow; Rades, Thomas; Boisen, Anja; Nielsen, Line Hagner

Publication date:

2016

Document Version

Peer reviewed version

Link back to DTU Orbit

Citation (APA):

von Halling Laier, C., Abid, Z., Weydahl, I. E. K., Rades, T., Boisen, A., \& Nielsen, L. H. (2016). Spray Drying of Cubosomes for Oral Vaccine Delivery. Poster session presented at 2016 AAPS Annual Meeting and Exposition, Denver, CO, United States.

\section{General rights}

Copyright and moral rights for the publications made accessible in the public portal are retained by the authors and/or other copyright owners and it is a condition of accessing publications that users recognise and abide by the legal requirements associated with these rights.

- Users may download and print one copy of any publication from the public portal for the purpose of private study or research.

- You may not further distribute the material or use it for any profit-making activity or commercial gain

- You may freely distribute the URL identifying the publication in the public portal

If you believe that this document breaches copyright please contact us providing details, and we will remove access to the work immediately and investigate your claim 


\section{PURPOSE}

To prepare cubosomes carrying the model antigen ovalbumin and the adjuvant Quil A using spray drying as method, as well as to in vitro characterize these particles.

\section{METHOD}

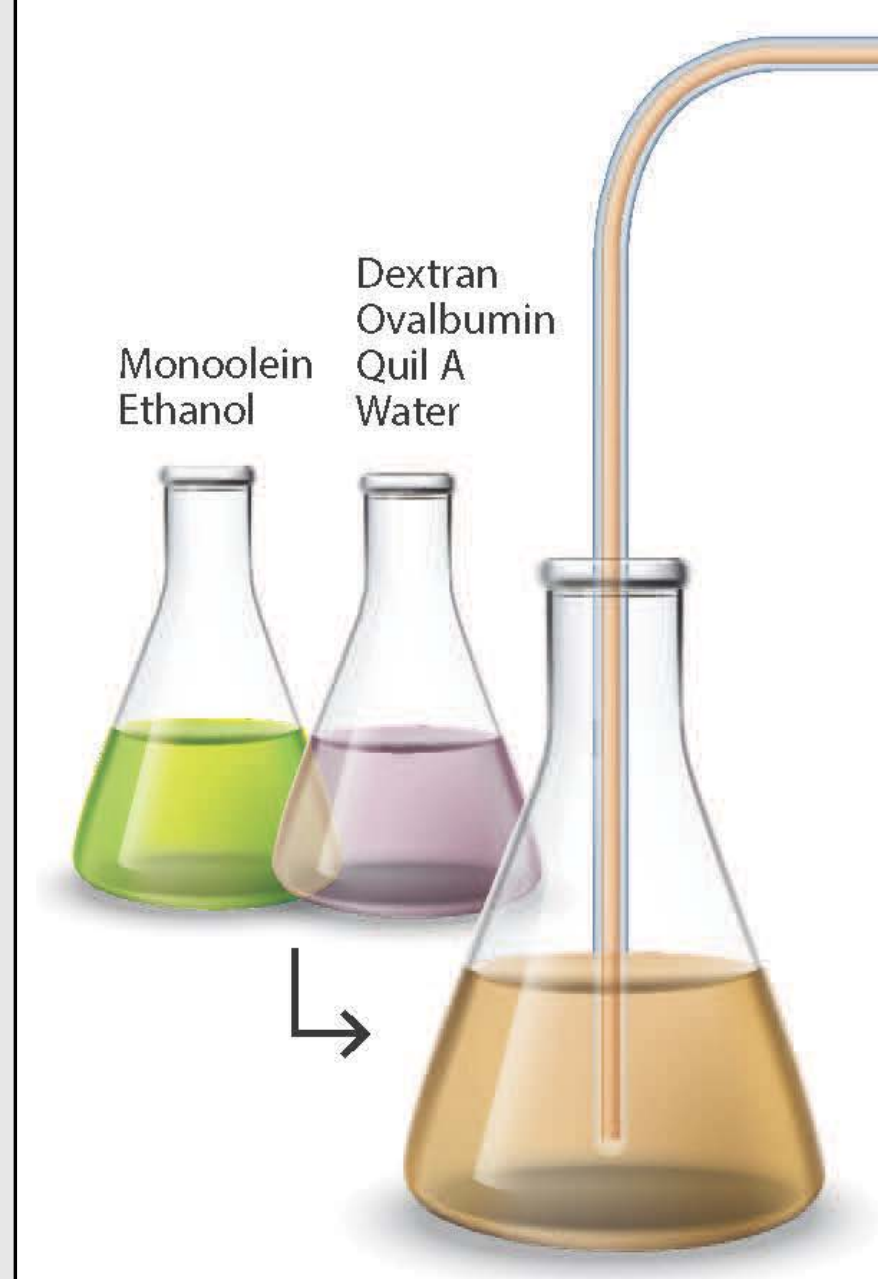

Monoolein, ethanol, dextran,
ovalbumin, Quil A and water

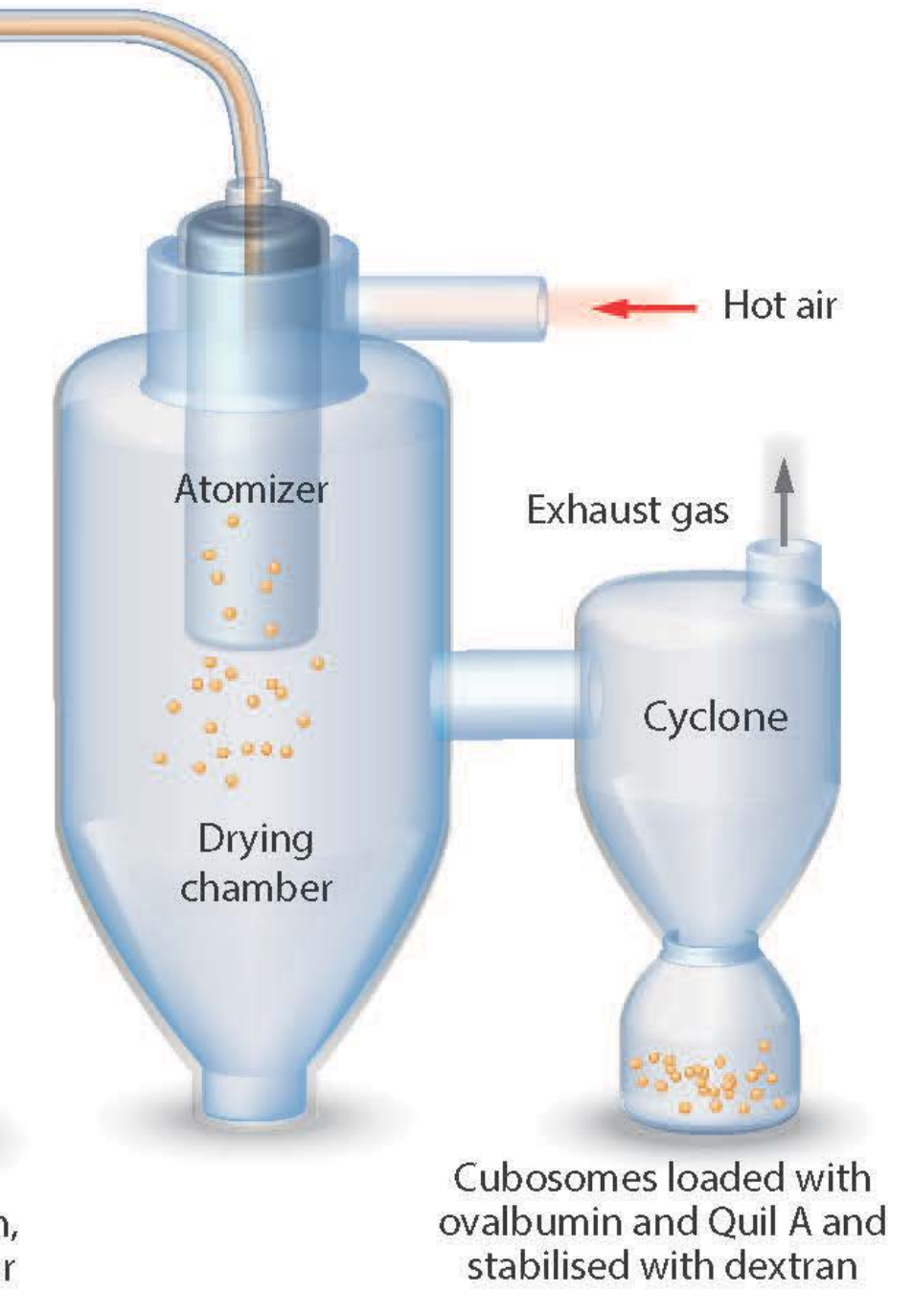

Fig. 1: $5.33 \mathrm{~W} / \mathrm{V} \%$ Dimodan ${ }^{\circledR}$ MO 90/D (high monoolein content) in ethanol is diluted by adding it to aqueous solution of dextran, ovalbumin (OVA) and Quil $A$ (2.67, 0.13 and $0.14 \mathrm{w} / \mathrm{V} \%$ respectively). The dilution of the ethanol causes immediate precipitation of lipid particles giving a turbid mixture in $24 \mathrm{~V} V$ thanol. The mixture is spray dried on a Büchi mini spray dryer.

\section{ACKNOWLEDGEMENTS}

\begin{tabular}{|c|c|}
\hline 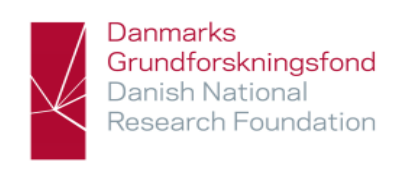 & VILLUM FONDEN \\
\hline DTU Nanotecl & דח \\
\hline
\end{tabular}

The research is funded by the Danish National Research Foundation (DNRF122) and Villum Fonden (Grant No. 9301)

We acknowledge the Core Facility for Integrated Microscopy, Faculty of Health and Medical Sciences, University of Copenhagen.

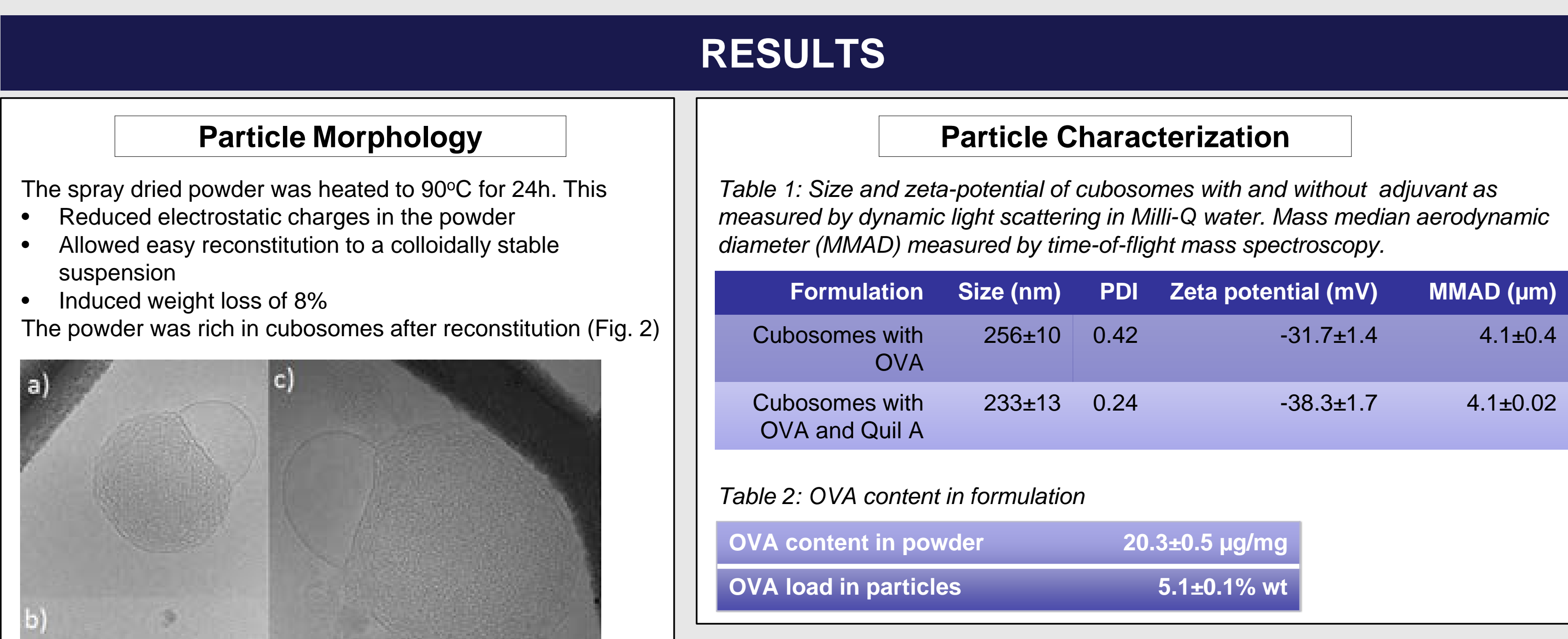

\section{Loading into microcontainers}

Microcontainers were fully and homogenously filled with cubosome powder by an embossing method. The microcontainers offer the possibility to protect the formulation during passage through the stomach and provide release of the cubosomes in the intestine.
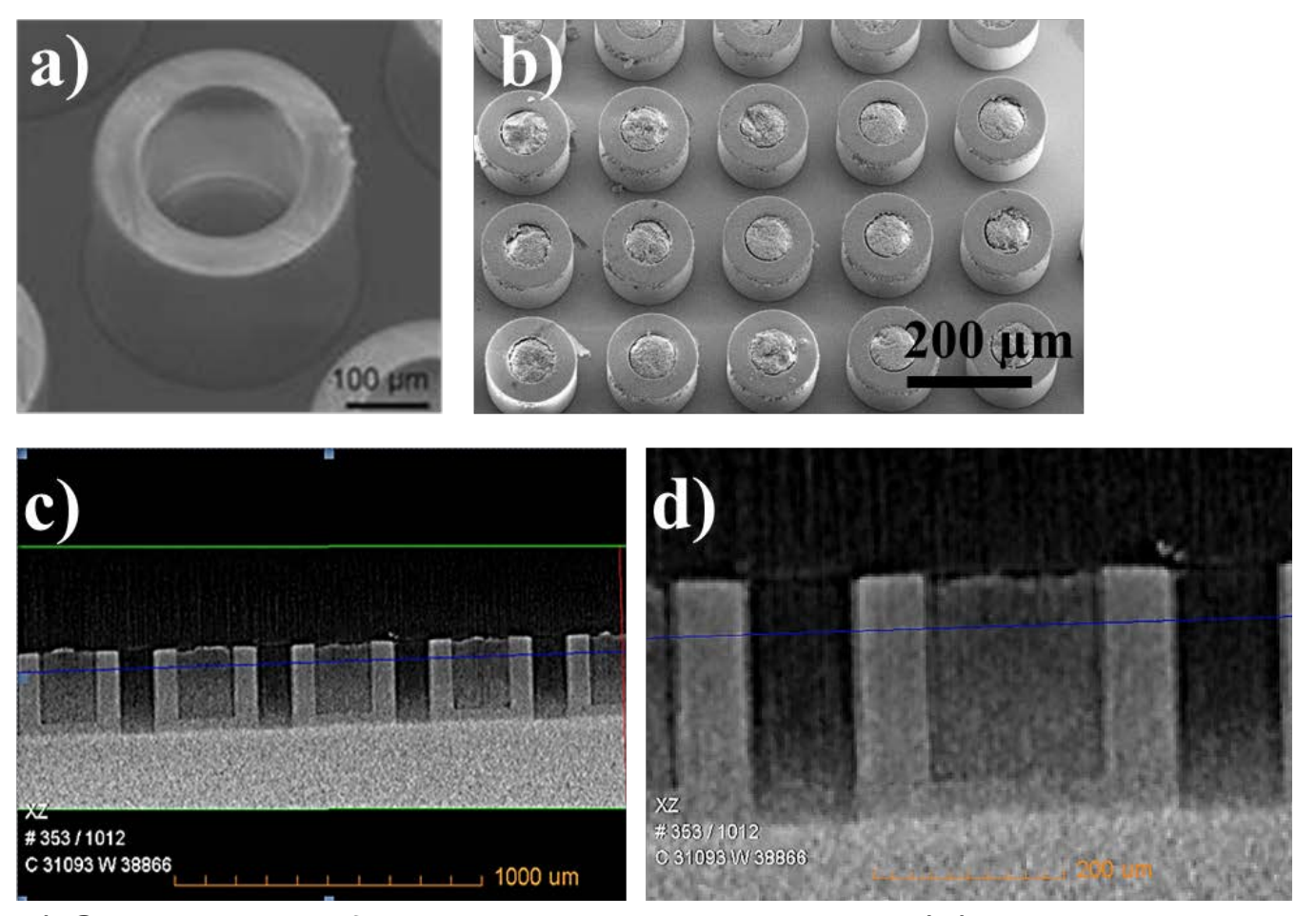

Fig. 4: $a+b)$ SEM image of and empty microcontainer (a) and microcontainers loaded with cubosomes (b). $c+d$ ) $X$-ray microtomography images of the loaded microcontainers.

\section{CONCLUSION}

